OPEN ACCESS

Edited by:

Rupesh Kailasrao Deshmukh,

Laval University, Canada

Reviewed by:

Sajad Majeed Zargar,

Sher-e-Kashmir University of

Agricultural Sciences and Technology,

India

Javaid Akhter Bhat,

Indian Agricultural Research Institute

(IARI), India

*Correspondence:

In-Jung Lee

ijlee@knu.ac.kr

Specialty section:

This article was submitted to

Plant Nutrition

a section of the journa

Frontiers in Plant Science

Received: 25 January 2017

Accepted: 23 March 2017

Published: 06 April 2017

Citation:

Kim Y-H, Khan AL, Waqas $M$ and

Lee I-J (2017) Silicon Regulates

Antioxidant Activities of Crop Plants under Abiotic-Induced Oxidative

Stress: A Review.

Front. Plant Sci. 8:510.

doi: $10.3389 /$ fpls.2017.00510

\section{Silicon Regulates Antioxidant} Activities of Crop Plants under Abiotic-Induced Oxidative Stress: A Review

\author{
Yoon-Ha Kim ${ }^{1,2}$, Abdul L. Khan ${ }^{3}$, Muhammad Waqas ${ }^{1,4}$ and In-Jung Lee ${ }^{1 *}$ \\ 1 Division of Plant Biosciences, Kyungpook National University, Daegu, South Korea, ${ }^{2}$ Division of Plant Sciences, University of \\ Missouri-Columbia, Columbia, MO, USA, ${ }^{3}$ UoN Chair of Oman's Medicinal Plants and Marine Natural Products, University of \\ Nizwa, Nizwa, Oman, ${ }^{4}$ Department of Agriculture, Abdul Wali Khan University Mardan, Khyber Pakhtunkhwa, Pakistan
}

Silicon (Si) is the second most abundant element in soil, where its availability to plants can exhilarate to $10 \%$ of total dry weight of the plant. Si accumulation/transport occurs in the upward direction, and has been identified in several crop plants. Si application has been known to ameliorate plant growth and development during normal and stressful conditions over past two-decades. During abiotic (salinity, drought, thermal, and heavy metal etc) stress, one of the immediate responses by plant is the generation of reactive oxygen species (ROS), such as singlet oxygen $\left({ }^{1} \mathrm{O}_{2}\right)$, superoxide $\left(\mathrm{O}_{2}^{-}\right)$, hydrogen peroxide $\left(\mathrm{H}_{2} \mathrm{O}_{2}\right)$, and hydroxyl radicals $(\mathrm{OH})$, which cause severe damage to the cell structure, organelles, and functions. To alleviate and repair this damage, plants have developed a complex antioxidant system to maintain homeostasis through non-enzymatic (carotenoids, tocopherols, ascorbate, and glutathione) and enzymatic antioxidants [superoxide dismutase (SOD), catalase (CAT), and ascorbate peroxidase (APX)]. To this end, the exogenous application of Si has been found to induce stress tolerance by regulating the generation of ROS, reducing electrolytic leakage, and malondialdehyde (MDA) contents, and immobilizing and reducing the uptake of toxic ions like $\mathrm{Na}$, under stressful conditions. However, the interaction of $\mathrm{Si}$ and plant antioxidant enzyme system remains poorly understood, and further in-depth analyses at the transcriptomic level are needed to understand the mechanisms responsible for the Si-mediated regulation of stress responses.

Keywords: oxidative stress, stress response, Si fertilization, biochemical and physiological function, stress in plants

\section{INTRODUCTION}

Silicon $(\mathrm{Si})$ has a strong affinity with oxygen; therefore, it usually exists as silica $\left(\mathrm{SiO}_{2}\right)$ under natural conditions (Ma and Takahashi, 2002). It also exists in the form of silicic acid $\left[\mathrm{Si}(\mathrm{OH})_{4}\right]$ and silicate $\left(\mathrm{xM}_{2}^{1} \mathrm{OySiO}_{2}\right)$, depending upon the soil $\mathrm{pH}$ (Epstein, 1999). Si accumulation/transport occurs in the upward direction, and has been identified in several crop plants. Si transporter genes have been identified in rice, barley, and maize roots, which facilitate its absorption from the soil to the shoot area. Subsequently, it stimulates various physiological responses such as growth, development, and optimization of enzymatic activities. Si accumulation in plant normally 
occurs from the root to shoot, and its transport process has been identified in several crops such as rice, maize, and barley ( $\mathrm{Ma}$ et al., 2006; Mitani et al., 2009; Cooke and Leishman, 2011; Yamaji et al., 2012). Two Si transporter genes were identified by $\mathrm{Ma}$ et al. (2006) in rice root and was named as low silicon gene 1 (Lsi1) and low silicon gene 2 (Lsi2). Following this several $\mathrm{Si}$ transport genes have been characterized in other corps such as barley (HvLsi1, HvLsi2) and maize (ZmLsi1, ZmLsi2; Ma et al., 2006; Mitani et al., 2009; Yamaji et al., 2012). After the absorption of $\mathrm{Si}$ from the soil into the root, it gets translocated to the shoot area, where it can stimulate various physiological responses, such as plant growth and development (Epstein, 1999; Hamayun et al., 2010; Kim et al., 2012; Mateos-Naranjo et al., 2015), enzymatic activity (Epstein, 1999; Liang et al., 2003; Gong et al., 2005; Kim et al., 2014a,b,c; Todorova et al., 2014; Abdel-Haliem et al., 2017), and gene expression (Ma and Yamaji, 2008; Kim et al., 2014a; Vatansever et al., 2017).

To complete a life cycle, plants are continuously exposed to various abiotic stresses and sometime multifaceted stresses. These stresses in turn causing the generation of various reactive oxygen species (ROS), such as singlet oxygen $\left({ }^{1} \mathrm{O}_{2}\right)$, superoxide $\left(\mathrm{O}_{2}^{-}\right)$, hydrogen peroxide $\left(\mathrm{H}_{2} \mathrm{O}_{2}\right)$, or hydroxyl radicals $(\mathrm{OH})$ in cells (Sharma et al., 2012; Das and Roychoudhury, 2014). These ROS can cause serious oxidative damage to the protein, DNA, and lipids of cell components (Apel and Hirt, 2004; Lobo et al., 2010; Tripathi et al., 2017). Therefore, ROS scavenging is most important defense mechanism to cope with stress condition in plants (Sharma et al., 2012; Baxter et al., 2014; Das and Roychoudhury, 2014). According to previous reports, exogenously $\mathrm{Si}$ can improve the ability of ROS scavenging by regulation of antioxidants enzyme activity (Torabi et al., 2015; Kim et al., 2016; Tripathi et al., 2017). Furthermore, regulation pattern across various crop plants is different depending upon the exposure time of the stress (Sharma et al., 2012; Kim et al., 2016). Therefore, here, we discussed various possibilities based on previous literature survey and our understanding the role of $\mathrm{Si}$ in modulating antioxidant activities in plants during abiotic stress.

\section{DEFENSE MECHANISM AGAINST ROS GENERATION}

In natural conditions, plants continuously produce several ROS during photosynthesis and respiration processes in cell organelles such as mitochondria, chloroplast, and peroxisomes. Thus, plants can maintain homeostasis by two different detoxification mechanisms involving non-enzymatic and enzymatic antioxidants (Mittler, 2002; Arbona et al., 2003; Apel and Hirt, 2004; Sytar et al., 2013; Wu et al., 2017). In plants, superoxide dismutase (SOD), catalase (CAT), and ascorbate peroxidase (APX) are the main enzymatic antioxidants, whereas carotenoids, tocopherols, ascorbate, and glutathione are classified as the non-enzymatic antioxidants (Asada, 1999; Racchi, 2013; Kim et al., 2014b,c). Racchi (2013) reported that SOD exists in various forms, such as $\mathrm{Cu} / \mathrm{ZnSOD}, \mathrm{MnSOD}$, and FeSOD. Depending upon their affinity with the other ions in plants, each SOD are distributed in a different form in various plant organs such as chloroplasts (Cu/ZnSOD, FeSOD), cytosol $(\mathrm{Cu} / \mathrm{ZnSOD})$, and mitochondria (MnSOD). Primarily, SOD catalyzes the efficient removal of superoxide free radicals in chloroplasts as they are mainly generated in the photosystem I during the light reaction. CAT is located in the peroxisomes of plant cells, and its main role is the elimination of $\mathrm{H}_{2} \mathrm{O}_{2}$, which is produced by the SOD reaction. Another antioxidant, APX, also can remove $\mathrm{H}_{2} \mathrm{O}_{2}$; however, it is distributed in the preoxisomes as well as chloroplasts, cytosol, and mitochondrion (Racchi, 2013). Thus, APX can be found in different forms, such as cAPX (cytosol), mitAPX (mitochondria), sAPX (chloroplast stroma), mAPX (peroxisomes and glyoxisomes), and tAPX (chloroplast thylakoids) depending upon its location (Racchi, 2013). In the chloroplast, APX exist as SAPX and tAPX; the ratio of sAPX and tAPX in chloroplast differs according to the plant species and leaf senescence, and reveals different plant sizes (Sun et al., 2010). The cAPX is located in cytosol; thus, its plays a role in the elimination of $\mathrm{H}_{2} \mathrm{O}_{2}$, which is generated in cytosol. Therefore, all APXs are different in characteristics such as size, location, role, and amino acid sequences (Caverzan et al., 2012).

Plants can induce defense responses against oxidative stress by activating the non-enzymatic antioxidants, which represent the second line of defense against ROS, hydrophilic molecules (ascorbate, glutathione), and lipophilic metabolites (carotenoids, $\alpha$-tocopherol; Racchi, 2013; Suzuki et al., 2014; Gowayed et al., 2017) Ascorbate is a water-soluble antioxidant synthesized in mitochondria. It can translocate to other cell compartments by two different pathways. Normally, ascorbate can directly scavenge $\operatorname{ROS}\left({ }^{1} \mathrm{O}_{2}, \mathrm{O}_{2}^{-}\right.$, and $\left.\mathrm{OH}\right)$ in the cell. Furthermore, it is connected with the de-epoxidase enzyme of violaxanthin, and acts as response matrix of APX (Szarka et al., 2013). Due to its various roles, ascorbate is considered as the most powerful antioxidant in the plant cell (Gill and Tuteja, 2010; Racchi, 2013; Suzuki et al., 2014). Glutathione is also an important water-soluble antioxidant, and plays an important role in scavenging ${ }^{1} \mathrm{O}_{2}$ and $\mathrm{OH}$ from chloroplasts (Sharma et al., 2012). In addition, glutathione protects the thiol-groups of enzymes located in the chloroplast stroma and participates in the production of $\alpha$-tocopherol and ascorbate (Xiang and Oliver, 1998; Hicks et al., 2007; Sharma et al., 2012; Racchi, 2013). Besides its role in detoxification of ROS, glutathione induces physiological responses such as the regulation of sulfur transport and expression of stress defense genes (Noctor et al., 2002; Racchi, 2013). Carotenoids are a class of phenolic compounds distributed in various fruits and vegetables (Racchi, 2013). They can prevent lipid peroxidation by scavenging single oxide radical from chloroplasts (Kühlbrandt et al., 1994). Carotenoids are synthesized in plastids and consist of 40-carbon isoprenoids. According to $\mathrm{Lu}$ and $\mathrm{Li}$ (2008), carotenoids are classified as carotenes, which include the carbon and hydrogen atoms, and xanthophylls that contain the oxygenated form of carotenes (Wu et al., 2017). The most important role of $\alpha$-tocopherol is that it can eliminate ${ }^{1} \mathrm{O}_{2}, \mathrm{O}_{2}^{-}$, and $\mathrm{OH}$ free radicals, which are generated in the thylakoid membranes; thus, it can prevent lipid peroxidation (Fryer, 1992; Kataria, 2017). $\alpha$-tocopherol has adequate fluidity, enabling it to move easily within the lipid 


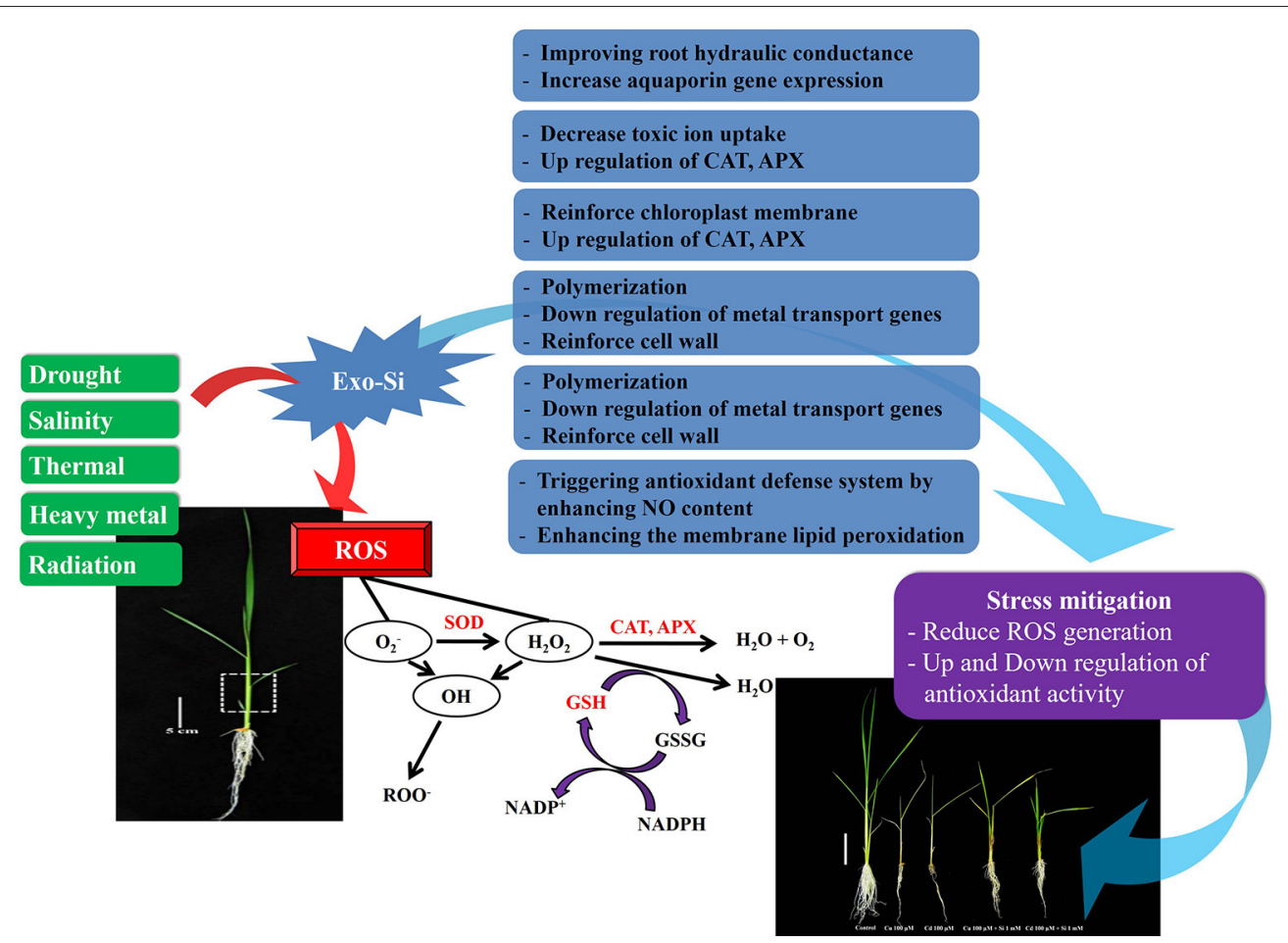

FIGURE 1 | Schematic presentation shows the possible causes that overproduce the reactive oxygen species that could disturb the normal function of cells. The mechanism of antioxidants shown here scavenges the ROS as well as Si effect to mitigate abiotic stress condition.

membrane. Thus, membrane safety is induced by the fluidity of $\alpha$-tocopherol (Faltin et al., 2010; Racchi, 2013; Figure 1).

\section{SI IN ROS SCAVENGING UNDER ABIOTIC STRESS CONDITIONS}

The enzymatic/non-enzymatic antioxidants are involved in the removal of ROS either directly (catalases and peroxidases) or indirectly through the regeneration of the two major redox molecules (ascorbate and glutathione) in the cells (Figure 1). Accumulation of these antioxidants suggests a high level of stress convened to the plants (Sharma et al., 2012). This could be also assumed that the plant has defended itself from ROS by producing high amount of antioxidant/enzymes. Accoring to Rouhier and Jacquot (2008), Si application in crops during abiotic stress conditions can regulate ROS generation. Here, we investigated via past and current reports that how antioxidant enzymes could regulate after exogenously $\mathrm{Si}$ to different plant species during some of the common abiotic stresses (salinity, drought, temperature, wounding, UV, and heavy metal stress).

\section{SALINITY STRESS}

Decrease in water potential due to high concentration of sodium and chloride ions inhibit plant growth and development (Torabi et al., 2015). According to Kim et al. (2014c), the application of $\mathrm{Si}$ in rice plants under salinity significantly decreased the activities of non-enzymatic MDA and enzymatic antioxidants POD, PPO, and CAT on the other hands, Torabi et al. (2015) observed that when they applied Si to borage plant, SOD activity was significantly increased in Si treatment but activity of CAT and APX was slightly decreased in Si application (Table 1). However, Shekari et al. (in press) found that activities of CAT, APX, SOD, and POD were highly increased under $\mathrm{Si}$ application with $\mathrm{NaCl}$ to herbal Anethum graveolens plants. Same pattern of SOD, GPX, APX, GR, and CAT activities was observed by Al-aghabary et al. (2005); Liang et al. (2003), and Zhu et al. (2004). The activities were significantly increased in Si applied barley, cucumber, and tomato plants (Table 1).

\section{DROUGHT STRESS}

Drought condition cause damage the photosynthetic pigments and disturb balance between ROS production and antioxidants thus overall affecting crop productivity (Iturbe-Ormaetxe et al., 1998; Gong et al., 2005). According to Gong et al. (2005), Si treatment in wheat plants caused high drought tolerance by up-regulating antioxidant activities of CAT, SOD, and GR (Table 1). Ma et al. (2016) also suggested that Si supplement wheat plant showed lower lipid peroxidation, glutathione and total flavonoid content whereas increased ascorbate content was observed. Similarly, Shi et al. $(2014,2016)$ reported that Si supplementation in tomato plants under PEG induced drought 
TABLE 1 | Modulation of antioxidant activities by Si application under various abiotic stresses.

\begin{tabular}{|c|c|c|c|}
\hline Abiotic stresses & Silicon effect & Crop plant & References \\
\hline Salinity & Increased activity of LPO & Barley & Liang et al., 2003 \\
\hline Salinity & $\begin{array}{l}\text { Increased activity of SOD, GPX, APX, and GR } \\
\text { Decreased activity of ELP and LPO }\end{array}$ & Cucumber & Zhu et al., 2004 \\
\hline Salinity & $\begin{array}{l}\text { Increased activity of SOD and CAT } \\
\text { Decreased activity of APX and MDA }\end{array}$ & Tomato & Al-aghabary et al., 2005 \\
\hline Salinity & Decreased activity of CAT, MDA, POD, and PPO & Rice & Kim et al., 2014c \\
\hline Salinity & $\begin{array}{l}\text { Increased activity of SOD } \\
\text { Decreased activity of CAT and APX }\end{array}$ & Borago & Torabi et al., 2015 \\
\hline Salinity & Increased activity of CAT, APX, SOD, and POD & Dill & Shekari et al., in press \\
\hline Drought & Increased activity of CAT, SOD, and GR & Wheat & Gong et al., 2005 \\
\hline Drought & $\begin{array}{l}\text { Increased ascorbate contents } \\
\text { Reduced glutathione and flavonoid contents }\end{array}$ & Wheat & Ma et al., 2016 \\
\hline Drought & Decreased activity of APX and MDA & Sunflower & Gunes et al., 2008 \\
\hline Drought & $\begin{array}{l}\text { Increased activity of SOD and CAT } \\
\text { Decreased activity of POD }\end{array}$ & Tomato & Shi et al., 2014 \\
\hline Drought & Increased activity of SOD and CAT & Tomato & Shi et al., 2016 \\
\hline High Tem. & $\begin{array}{l}\text { Increased activity of SOD, APX, and GPX } \\
\text { Decreased activity of CAT }\end{array}$ & Salvia splendens & Soundararajan et al., 2014 \\
\hline Low Tem. & $\begin{array}{l}\text { Increased activity of SOD, GSH, APX, MDHAR, GR, and AsA } \\
\text { Decreased activity of MDA }\end{array}$ & Cucumber & Liu et al., 2009 \\
\hline Low Tem. & $\begin{array}{l}\text { Increased activity of GSH and AsA } \\
\text { Decreased activity of MDA }\end{array}$ & Maize & Habibi, 2016 \\
\hline Low Tem. & $\begin{array}{l}\text { Increased activity of SOD, CAT, and POD } \\
\text { Decreased activity of MDA }\end{array}$ & Turfgrass & He et al., 2010 \\
\hline Mechanical Wounding & $\begin{array}{l}\text { Increased activity of CAT, POD and PPO } \\
\text { Decreased activity of MDA }\end{array}$ & Rice & Kim et al., 2016 \\
\hline Ultraviolet-B & Decreased activity of CAT and POD & Soybean & Shen et al., 2010 \\
\hline Ultraviolet-B & $\begin{array}{l}\text { Increased activity of SOD and APX } \\
\text { Decreased activity of CAT and GPX }\end{array}$ & Wheat & Tripathi et al., 2017 \\
\hline Heavy metal (Cd) & Decreased activity of MDA & Rice & Kim et al., $2014 a$ \\
\hline Heavy metal (Mn) & Decreased activity of POD & Cucumber & Maksimović et al., 2012 \\
\hline Heavy metal (Cr) & $\begin{array}{l}\text { Increased activity of SOD, GR, and CAT } \\
\text { Decreased activity of APX }\end{array}$ & Pea & Tripathi et al., 2015 \\
\hline
\end{tabular}

APX, ascorbate peroxidase; CAT, catalase; GSH, glutathione reduced form; GR, glutathione reductase; GPX, guaiacol peroxidase; LPO, lipid peroxidase; SOD, superoxide dismutase; ELP, electrolytic leakage percentage; MDA, malondialdehyde; POD, peroxidase; PPO, polyphenol peroxidase; MDHAR, monodehydroascorbate reductase; AsA, ascorbate.

stress caused tolerance via increased SOD and CAT activities as well as improved water uptake ability of roots (Table 1). Whilst, Gunes et al. (2008) observed that Si decreased MDA and APX activities in sunflower during drought condition (Table 1).

\section{THERMAL STRESS}

Like other abiotic stress factors, thermo (cold and heat) stress may also disturb the balance between ROS and antioxidants activity. Soundararajan et al. (2014) treated Salvia splendens with $\mathrm{Si}$ under high temperature $\left(35^{\circ} \mathrm{C}\right)$, and found that the activities of SOD, APX and GPX were increased and contrarily that of CAT was decreased (Table 1). Liu et al. (2009) observed that during low temperature (day/night; $15 / 8^{\circ} \mathrm{C}$ ), Si applied to hydroponically cultivated cucumber plant were more resistant to chilling stress compared to non-Si application and was attributed to more activated antioxidants such as SOD, GSH, APX, GR,
MDHAR, and AsA (Table 1). Almost same tendency of chilling (day/night; $15 / 5^{\circ} \mathrm{C}$ ) stress tolerance was observed in turf grass as well, after $\mathrm{Na}_{2} \mathrm{SiO}_{3}$ fertilization into soil (He et al., 2010; Habibi, 2016; Table 1).

\section{MECHANICAL WOUNDING}

Normally, natural wounding stress is caused by herbivory or lodging and these events could increase hydrogen peroxide level inside plant tissues (León et al., 2001). According to Kim et al. (2014a), exogenous Si application in rice plants improved mechanical strength to overcome losses from wounding stress (Table 1).

\section{ULTRAVIOLET-B}

Many studies demonstrated that $\mathrm{Si}$ application can induce resistance to UV-B stress via physiological and biochemical 
process in plants (Tripathi et al., 2017). In particular, when UV$\mathrm{B}$ applied to tropical plants, MDA, POD, SOD, and anthocyanin contents was increased however, they found decreased activity of CAT was measured (Todorova et al., 2014; Table 1). According to Tripathi et al. (2017), UV stress was significantly improved at $\mathrm{Si}$ and $\mathrm{Si}$ nanoparticle ( $\mathrm{SiNp}$ ) applied wheat seedlings. Especially, mitigation effects between $\mathrm{Si}$ and SiNp showed that SiNp applied wheat seedling revealed more strong resistance to UV-B stress (Table 1). Other study reported that decreased activity of POD and CAT were measured when they applied Si with UV-B stress to soybean plants (Shen et al., 2010; Table 1).

\section{HEAVY METAL STRESS}

In addition, during heavy metal stress, $\mathrm{Si}$ application can regulate metal transport and prevent damage shown by decreased MDA activity in rice plants (Kim et al., 2016). In cucumber, $\mathrm{Si}$ application can ameliorate manganese toxicity observed by decreased POD activity (Maksimović et al., 2012; Table 1). Tripathi et al. (2015) applied SiNp with chromium $(\mathrm{Cr})$ to pea seedling after that, they confirmed stress tolerance phenotypes such as enhanced photosynthetic pigments as well as increased activity of SOD, GR, and CAT however, APX activity was decreased (Table 1).

\section{REFERENCES}

Abdel-Haliem, M. E., Hegazy, H. S., Hassan, N. S., and Naguib, D. M. (2017). Effect of silica ions and nano silica on rice plants under salinity stress. Ecol. Eng. 99, 282-289. doi: 10.1016/j.ecoleng.2016.11.060

Al-aghabary, K., Zhu, Z., and Shi, Q. (2005). Influence of silicon supply on chlorophyll content, chlorophyll fluorescence, and antioxidative enzyme activities in tomato plants under salt stress. J. Plant Nut. 27, 2101-2115. doi: 10.1081/PLN-200034641

Apel, K., and Hirt, H. (2004). Reactive oxygen species: metabolism, oxidative stress, and signal transduction. Annu. Rev. Plant Biol. 55, 373-399. doi: 10.1146/annurev.arplant.55.031903.141701

Arbona, V., Flors, V., Jacas, J., García-Agustín, P., and Gómez-Cadenas, A. (2003). Enzymatic and non-enzymatic antioxidant responses of Carrizo citrange, a saltsensitive citrus rootstock, to different levels of salinity. Plant Cell Physiol. 44, 388-394. doi: 10.1093/pcp/pcg059

Asada, K. (1999). The water-water cycle in chloroplasts: scavenging of active oxygens and dissipation of excess photons. Ann. Rev. Plant Physiol. Plant Mol. Biol. 50, 601-639. doi: 10.1146/annurev.arplant.50.1.601

Baxter, A., Mittler, R., and Suzuki, N. (2014). ROS as key players in plant stress signalling. J. Exp. Bot. 65, 1229-1240. doi: 10.1093/jxb/ ert375

Caverzan, A., Passaia, G., Barcellos Rosa, S. B., Werner Riveiro, C. W., Lazzarotto, F., and Margis-Pinheiro, M. (2012). Plant responses to stresses: role of ascorbate peroxidse in the zntioxidant protection. Genet. Mol. Biol. 35, 1011-1019. doi: 10.1590/S1415-47572012000600016

Cooke, J., and Leishman, M. R. (2011). Is plant ecology more siliceous than we realise? Trends Plant Sci. 16, 61-68. doi: 10.1016/j.tplants.2010.10.003

Das, K., and Roychoudhury, A. (2014). Reactive oxygen species (ROS) and response of antioxidants as ROS-scavengers during environmental stress in plants. Front Environ Sci. 2:53. doi: 10.3389/fenvs.2014.00053

Epstein, E. (1999). Silicon. Annu. Rev. Plant Physiol. Plant Mol. Biol. 50, 641-664. doi: 10.1146/annurev.arplant.50.1.641

\section{CONCLUSIONS}

During abiotic stress conditions, the $\mathrm{Si}$ application shows varying response to ROS scavenging by activating the defense system plants. In doing so, the activity of antioxidant arsenals (CAT, SOD, PPO, POD, APX, GPX, and GSSH) may also oscillate depending upon the intensity of stress and plant type. Si supplemented plants showed resistance to abiotic stress through, lowering ROS production by (i) enhancing CAT and APX activities as both are involved in conversion of $\mathrm{H}_{2} \mathrm{O}_{2}$ into $\mathrm{H}_{2} \mathrm{O}$ (ii) and decreasing MDA activity.

\section{AUTHOR CONTRIBUTIONS}

YK wrote the manuscript; MW and AK contributed in drafting and revising manuscript; IL draw the figure and revised the manuscript.

\section{FUNDING}

This work was supported by Korea Institute of Planning and Evaluation for Technology in Food, Agriculture, Forestry and Fisheries (IPET) through Agriculture, Food and Rural Affairs Research Center Support Program, funded by Ministry of Agriculture, Food and Rural Affairs (MAFRA) (716001-7)

Faltin, Z., Holland, D., Velcheva, M., Tsapovetsky, M., Roeckel-Drevet, P., Handa, A. K., et al. (2010). Glutathione peroxidase regulation of reactive oxygen species level is crucial for in vitro plant differentiation. Plant Cell Physiol. 51, 1151-1162. doi: $10.1093 / \mathrm{pcp} / \mathrm{pcq} 082$

Fryer, M. J. (1992). The antioxidant effects of thylakoid vitamin E ( $\alpha$-tocopherol). Plant Cell Environ. 15, 381-392. doi: 10.1111/j.1365-3040.1992.tb00988.x

Gill, S. S., and Tuteja, N. (2010). Reactive oxygen species and antioxidant machinery in aboitic stress tolerance in crop plants. Plant Physiol. Biochem. 48, 909-930. doi: 10.1016/j.plaphy.2010.08.016

Gong, H., Zhu, X., Chen, K., Wang, S., and Zhang, C. (2005). Silicon alleviates oxidative damage of wheat plants in pots under drought. Plant Sci. 169, 313-321. doi: 10.1016/j.plantsci.2005.02.023

Gowayed, S. M., Al-Zahrani, H. S., and Metwali, E. M. (2017). Improving the Salinity tolerance in potato (Solanum tuberosum) by exogenous application of silicon dioxide nanoparticles. Int. J. Agric. Biol. 19, 183-194. doi: 10.17957/IJAB/15.0262

Gunes, A., Pilbeam, D. J., Inal, A., and Coban, S. (2008). Influence of silicon on sunflower cultivars under drought stress, I: growth, antioxidant mechanisms, and lipid peroxidation. Commun. Soil Sci. Plant Anal. 39, 1885-1903. doi: 10.1080/00103620802134651

Habibi, G. (2016). Effect of foliar-applied silicon on photochemistry, antioxidant capacity and growth in maize plants subjected to chilling stress. Acta Agric. Slov 107, 33-43. doi: 10.14720/aas.2016.107.1.04

Hamayun, M., Sohn, E. Y., Khan, S. A., Shinwari, Z. K., Khan, A. L., and Lee, I. J. (2010). Silicon alleviates the adverse effects of salinity and drought stress on growth and endogenous plant growth hormones of soybean (Glycine max L.). Pak. J. Bot. 42, 1713-1722.

He, Y., Xiao, H., Wang, H., Chen, Y., and Yu, M. (2010). Effect of silicon on chilling-induced changes of solutes, antioxidants, and membrane stability in seashore paspalum turfgrass. Acta Physiol. Plant 32, 487-494. doi: 10.1007/s11738-009-0425-x

Hicks, L. M., Cahoon, R. E., Bonner, E. R., Rivard, R. S., Sheffield, J., and Jez, J. M. (2007). Thiol-based regulation of redox-active glutamate-cysteine ligase 
from Arabidopsis thaliana. Plant Cell 19, 2653-2661. doi: 10.1105/tpc.107. 052597

Iturbe-Ormaetxe, I., Escuredo, P. R., Arrese-Igor, C., and Becana, M. (1998). Oxidative damage in pea plants exposed to water deficit or paraquat. Plant physiology 116, 173-181. doi: 10.1104/pp.116.1.173

Kataria, S. (2017). "Chapter 6: Oxidative stress and antioxidative defence system in plants in response to UVB stress," in UV-B Radiation: From Environmental Stressor to Regulator of Plant Growth, eds V. P. Singh, S. Singh, S. M. Prasad, and P. Parihar (New York, NY: John Wiley \& Sons), 99-122.

Kühlbrandt, W., Wang, D. N., and Fujiyoshi, Y. (1994). Atomic model of plant light-harvesting complex by electron crystallography. Nature 367, 614-621. doi: $10.1038 / 367614 \mathrm{a} 0$

Kim, Y. H., Khan, A. L., Kim, D. H., Lee, S. Y., Kim, K. M., Waqas, M., et al. (2014a). Silicon mitigates heavy metal stress by regulating P-type heavy metal ATPases, Oryza sativa low silicon genes, and endogenous phytohormones. BMC Plant Biol. 14:13. doi: 10.1186/1471-2229-14-13

Kim, Y. H., Khan, A. L., Shinwari, Z. K., Kim, D. H., Waqas, M., Kamran, M., et al. (2012). Silicon treatment to rice (Oryza sativa L. cv.'Gopumbyeo') plants during different growth periods and its effects on growth and grain yield. Pak. J. Bot. 44, 891-897.

Kim, Y. H., Khan, A. L., Waqas, M., Jeong, H. J., Kim, D. H., Shin, J. S., et al. (2014b). Regulation of jasmonic acid biosynthesis by silicon application during physical injury to Oryza sativa L. J. Plant Res. 127, 525-532. doi: 10.1007/s10265-014-0641-3

Kim, Y. H., Khan, A. L., Waqas, M., Shahzad, R., and Lee, I. J. (2016). Silicon-mediated mitigation of wounding stress acts by up-regulating the rice antioxidant system. Cereal Res. Commun. 44, 111-121. doi: 10.1556/0806.43.2015.031

Kim, Y. H., Khan, A. L., Waqas, M., Shim, J. K., Kim, D. H., Lee, K. Y., et al. (2014c). Silicon application to rice root zone influenced the phytohormonal and antioxidant responses under salinity stress. J. Plant Growth Regul. 33, 137-149. doi: 10.1007/s00344-013-9356-2

León, J., Rojo, E., and Sánchez Serrano, J. J. (2001). Wound signalling in plants. J. Exp. Bot. 52, 1-9. doi: 10.1093/jxb/52.354.1

Liang, Y., Chen, Q., Liu, Q., Zhang, W., and Ding, R. (2003). Exogenous silicon (Si) increases antioxidant enzyme activity and reduces lipid peroxidation in roots of salt-stressed barley (Hordeum vulgare L.). J. Plant Physiol. 160, 1157-1164. doi: 10.1078/0176-1617-01065

Liu, J. J., Lin, S. H., Xu, P. L., Wang, X. J., and Bai, J. G. (2009). Effects of exogenous silicon on the activities of antioxidant enzymes and lipid peroxidation in chilling-stressed cucumber leaves. Agr. Sci. China 8, 1075-1086. doi: 10.1016/S1671-2927(08)60315-6

Lobo, V., Patil, A., Phatak, A., and Chandra, N. (2010). Free radicals, antioxidants and functional foods: impact on human health. Pharmacogn Rev. 4, 118-126. doi: 10.4103/0973-7847.70902

Lu, S., and Li, L. (2008). Carotenoid metabolism: biosynthesis, regulation, and beyond. J. Integr. Plant Biol. 50, 778-785. doi: 10.1111/ j.1744-7909.2008.00708.x

Ma, D., Sun, D., Wang, C., Qin, H., Ding, H., Li, Y., et al. (2016). Silicon application alleviates drought stress in wheat through transcriptional regulation of multiple antioxidant defense pathways. J. Plant Growth Regul. 35, 1-10. doi: $10.1007 /$ s00344-015-9500-2

Ma, J. F., and Takahashi, E. (2002). Soil, Fertilizer, and Plant Silicon Research in Japan. Amsterdam: Elsevier.

Ma, J. F., Tamai, K., Yamaji, N., Mitani, N., Konishi, S., Katsuhara, M., et al. (2006). A silicon transporter in rice. Nature 440, 688-691. doi: 10.1038/nature04590

Ma, J. F., and Yamaji, N. (2008). Functions and transport of silicon in plants. Cell Mol. Life Sci. 65, 3049-3057. doi: 10.1007/s00018-008-7580-x

Maksimović, J. D., Mojović, M., Maksimović, V., Römheld, V., and Nikolic, M. (2012). Silicon ameliorates manganese toxicity in cucumber by decreasing hydroxyl radical accumulation in the leaf apoplast. J. Exp. Bot. 63, 2411-2420. doi: $10.1093 / \mathrm{jxb} / \mathrm{err} 359$

Mateos-Naranjo, E., Galle, A., Florez-Sarasa, I., Perdomo, J. A., Galmés, J., Ribas-Carbó, M., et al. (2015). Assessment of the role of silicon in the $\mathrm{Cu}-$ tolerance of the C 4 grass Spartina densiflora. J. Plant Physiol. 178, 74-83. doi: 10.1016/j.jplph.2015.03.001

Mitani, N., Chiba, Y., Yamaji, N., and Ma, J. F. (2009). Identification and characterization of maize and barley Lsi2-like silicon efflux transporters reveals a distinct silicon uptake system from that in rice. Plant Cell 21, 2133-2142. doi: $10.1105 /$ tpc. 109.067884

Mittler, R. (2002). Oxidative stress, antioxidants and stress tolerance. Trends Plant Sci. 7, 405-410. doi: 10.1016/S1360-1385(02)02312-9

Noctor, G., Gomez, L., Vanacker, H., and Foyer, C. H. (2002). Interactions between biosynthesis, compartmentation and transport in the control of glutathione homeostasis and signaling. J. Exp. Bot. 53, 1283-1304. doi: 10.1093/jexbot/53.372.1283

Racchi, M. L. (2013). Antioxidant defenses in plants with attention to Prunus and Citrus spp. Antioxidants 2, 340-369. doi: 10.3390/antiox2040340

Rouhier, N., and Jacquot, J. P. (2008). Getting sick may help plants overcome abiotic stress. New Phytol. 180, 738-741. doi: 10.1111/j.1469-8137.2008. 02673.x

Sharma, P., Jha, A. B., Dubey, R. S., and Pessarakli, M. (2012). Reactive oxygen species, oxidative damage, and antioxidative defense mechanism in plants under stressful conditions. J. Bot. 2012:217037. doi: 10.1155/2012/ 217037

Shekari, F., Abbasi, A., and Mustafavi, S. H. (in press). Effect of silicon and selenium on enzymatic changes and productivity of dill in saline condition. J. Saudi Soc. Agric. Sci. doi: 10.1016/j.jssas.2015.11.006

Shen, X., Zhou, Y., Duan, L., Li, Z., Eneji, A. E., and Li, J. (2010). Silicon effects on photosynthesis and antioxidant parameters of soybean seedlings under drought and ultraviolet-B radiation. J. Plant Physiol. 167, 1248-1252. doi: 10.1016/j.jplph.2010.04.011

Shi, Y., Zhang, Y., Han., W., Feng, R., Hu, Y., Guo, J., et al. (2016). Silicon enhances water stress tolerance by improving root hydraulic conductance in Solanum lycopersicum L. Front. Plant Sci. 7:196. doi: 10.3389/fpls.2016. 00196

Shi, Y., Zhang, Y., Yao, H., Wu, J., Sun, H., and Gong, H. (2014). Silicon improves seed germination and alleviates oxidative stress of bud seedlings in tomato under water deficit stress. Plant Physiol. Biochem. 78, 27-36. doi: 10.1016/j.plaphy.2014.02.009

Soundararajan, P., Sivanesan, I., Jana, S., and Jeong, B. R. (2014). Influence of silicon supplementation on the growth and tolerance to high temperature in Salvia splendens. Hort. Environ. Biotechnol. 55, 271-279. doi: 10.1007/s13580-014-0023-8

Sun, W. H., Duan, M., Shu, D. F., Yang, S., and Meng, Q. W. (2010). Overexpression of tomato tAPX gene in tobacco improves tolerance to high or low temperature stress. Biol. Plant 54, 614-620. doi: 10.1007/s10535-0100111-2

Suzuki, N., Rivero, R. M., Shulaev, V., Blumwald, E., and Mittler, R. (2014). Abiotic and biotic stress combinations. New Phytol. 203, 32-43. doi: 10.1111/nph. 12797

Sytar, O., Kumar, A., Latowski, D., Kuczynska, P., Strzałka, K., and Prasad, M. N. V. (2013). Heavy metal-induced oxidative damage, defense reactions, and detoxification mechanisms in plants. Acta Physiol. Plant 35, 985-999. doi: 10.1007/s11738-012-1169-6

Szarka, A., Bánhegyi, G., and Asard, H. (2013). The inter-relationship of ascorbate transport, metabolism and mitochondrial, plastidic respiration. Antioxid Redox Signal. 19, 1036-1044. doi: 10.1089/ars.2012.5059

Todorova, D., Sergiev, I., Moskova, I., Katerova, Z., Georgieva, N., Alexieva, V., et al. (2014). Biochemical responses of triticale plants treated with UV-B irradiation and nutrient solution enriched with humic acids. Turkish J. Bot. 38, 747-753. doi: 10.3906/bot-1312-52

Torabi, F., Majd, A., and Enteshari, S. (2015). The effect of silicon on alleviation of salt stress in borage (Borago officinalis L.). Soil Sci. Plant Nut. 61, 788-798. doi: 10.1080/00380768.2015.1005540

Tripathi, D. K., Singh, S., Singh, V. P., Prasad, S. M., Dubey, N. K., and Chauhan, D. K. (2017). Silicon nanoparticles more effectively alleviated UV-B stress than silicon in wheat (Triticum aestivum) seedlings. Plant Physiol. Biochem. 110, 70-81. doi: 10.1016/j.plaphy.2016. 06.026

Tripathi, D. K., Singh, V. P., Prasad, S. M., Chauhan, D. K., and Dubey, N. K. (2015). Silicon nanoparticles (SiNp) alleviate chromium (VI) phytotoxicity in Pisum sativum (L.) seedlings. Plant Physiol. Biochem. 96, 189-198. doi: 10.1016/j.plaphy.2015.07.026

Vatansever, R., Ozyigit, I. I., Filiz, E., and Gozukara, N. (2017). Genomewide exploration of silicon ( $\mathrm{Si}$ ) transporter genes, Lsi1 and Lsi2 in plants; 
insights into Si-accumulation status/capacity of plants. BioMetals 30, 185-200. doi: 10.1007/s10534-017-9992-2

Wu, Z., Liu, S., Zhao, J., Wang, F., Du, Y., Zou, S., et al. (2017). Comparative responses to silicon and selenium in relation to antioxidant enzyme system and the glutathione-ascorbate cycle in flowering Chinese cabbage (Brassica campestris L. ssp. chinensis var. utilis) under cadmium stress. Environ. Exp. Bot. 133, 1-11. doi: 10.1016/j.envexpbot.2016.09.005

Xiang, C., and Oliver, D. J. (1998). Glutathione metabolic genes coordinately respond to heavy metals and jasmonic acid in Arabidopsis. Plant Cell 10, 1539-1550. doi: 10.1105/tpc.10.9.1539

Yamaji, N., Chiba, Y., Mitani-Ueno, N., and Ma, J. F. (2012). Functional characterization of a silicon transporter gene implicated in silicon distribution in barley. Plant Physiol. 160, 1491-1497. doi: 10.1104/pp.112. 204578
Zhu, Z., Wei, G., Li, J., Qian, Q., and Yu, J. (2004). Silicon alleviates salt stress and increases antioxidant enzymes activity in leaves of salt-stressed cucumber (Cucumis sativus L.). Plant Sci 167, 527-533. doi: 10.1016/j.plantsci.2004.04.020

Conflict of Interest Statement: The authors declare that the research was conducted in the absence of any commercial or financial relationships that could be construed as a potential conflict of interest.

Copyright (c) $2017 \mathrm{Kim}$, Khan, Waqas and Lee. This is an open-access article distributed under the terms of the Creative Commons Attribution License (CC BY). The use, distribution or reproduction in other forums is permitted, provided the original author(s) or licensor are credited and that the original publication in this journal is cited, in accordance with accepted academic practice. No use, distribution or reproduction is permitted which does not comply with these terms. 